\title{
Bone Marrow Smear
}

National Cancer Institute

\section{Source}

National Cancer Institute. Bone Marrow Smear. NCI Thesaurus. Code C77609.

A specimen prepared by spreading cells from bone marrow aspirate thinly on a glass slide for microscopic examination. The study of bone marrow smears is routinely used for the investigation, diagnosis, and staging of hematopoietic disorders. 